International Journal of Social Sciences and Humanities
Available online at http://sciencescholar.us/journal/index.php/ijssh
Vol. 1 No. 3, December 2017, pages: 182 193
e-ISSN: 2550-7001, p-ISSN: 2550-701X
http://dx.doi.org/10.29332/ijssh.v1n3.129

\title{
The Enrichment of New Vocabularies in Sasak Language Because of Gold Mining Spreading in Sekotong West Lombok
}

\section{Muliadi Alkapitani a , Syahdan ${ }^{\mathrm{b}}$, Priyono ${ }^{\mathrm{c}}$,}

Article history: Received 10 August 2017, Accepted in revised form 17 December 2017, Approved 27 December 2017, Available online 31 December 2017

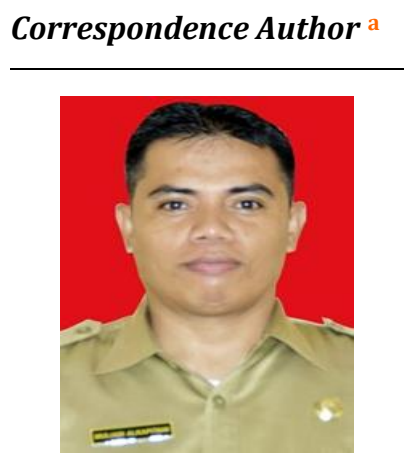

Keywords

Bound morpheme;

Morphology;

Sasak language;

Sekotong community;

Vocabulary;

\section{Abstract}

This study aims at describing 1) what new forms of vocabulary are, 2) how new vocabulary is accepted by Sekotong community, and 3) why the Sekotong community received a new vocabulary as a form of Sasak language enrichment. The approach used to discover the data in this study was linguistic approach with micro part by looking at the side of words that belongs to the morphology study. In the early stage, this research employed observation method in the early stages and followed by data collection, data classification, and data analysis. Data collection in this research was done through in-depth interviews by applying recording and defect techniques. The data were gathered from the informant as a source of data. The data analysis was firstly conducted by looking the data classified. Further, the data were analyzed in terms of the types of words consisting of nouns, verbs, adjective and the numeral. In addition, to analyze the word of the word class the data, it is also seen in terms of free morpheme and bound morpheme by the meaning of lexical, grammatical and contextual meaning.

e-ISSN : 2550-7001, $p$-ISSN : 2550-701X ๑ Copyright 2017. The Author. SS Journals Published by Universidad Técnica de Manabí. This is an open-access article under the CC BY-SA 4.0 license (https://creativecommons.org/licenses/by-sa/4.0/) All rights reserved.

\section{Contents}

Abstract

1. Introduction

2. Research Methods 186

3. Results and Analysis 187 3.1 Analysis of Data of Noun 


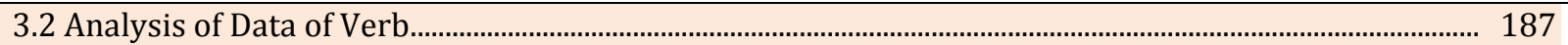

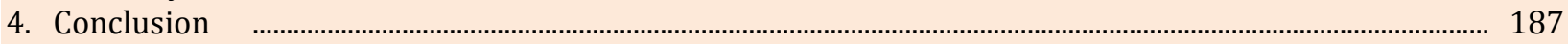

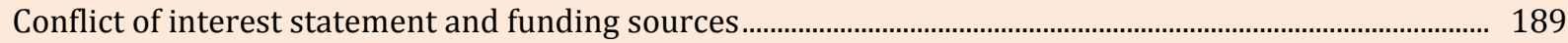

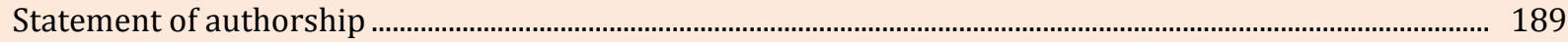

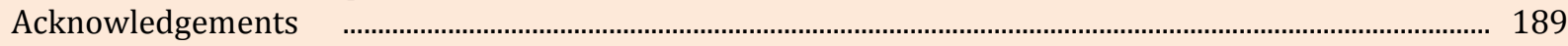

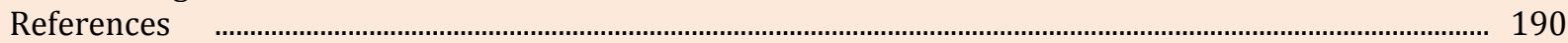

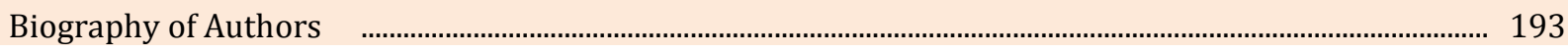

\section{Introduction}

A language with its regulatory system is a container that has patterns or rules obeyed and used (sometimes involuntarily) by speakers in a mutual understanding community. Sudaryanto (cited in Muhammad, 2011) states that language has five substances namely language identity, language principles, language components, language properties and language exponents. In line with many studies, many language aspects can be researched and studied such as the language itself, the elements of sounds as a language material, subject outside the sound like meaning, referent, usability, and language.

The reality of language use as a social fact such as all lifestyle associated with human relations with humans can only be transmitted using language. Any understanding and activity can only be passed on to the next generation through the language. This role is in line with Wijana and Rohmadi (2013) claiming that language is not only used in daily life but the language is also needed to carry out all activities of human life such as research, counseling, preaching even to convey thoughts, views, and feelings.

Linguistics in approaching the language becoming the object of its study is not as anything but as a language. The language approach as a language is in line with the essential features of language referring to the following concepts proposed by Chaer (2012). First, since language is the speech sound, then linguistics sees language as sound. It means that for linguistic, oral language is the primary while the writing language is only secondary. In traditional language studies, which do not approach languages like modern linguistics, we usually find statements like "Sentences are orderly arrangements beginning with a capital letter and end with a dot."

Secondly, because language is unique, linguistic does not attempt to use a language framework to impose on other languages. For example, there are many linguists examining Bahasa Indonesia by using a framework or concept applied in Latin, Greek, or Arabic, so that we now inherit concepts which are not appropriate with Bahasa such as the concept of compound words, word pressure, and the concept of the article. The approach to language conducted by researchers did not see that every language has its own unique or distinctive features; although, admittedly there are similarities between systems of language with other.

Language is an arbitrary and meaningful symbol of the sound system which is always conventionally used by human, unique, varied and productive. In a social group, to learn things related to the social identity of the social group, social attitudes toward language, the variety of standard and non-native languages, the patterns and needs of the use of the national language, the social variation and the level of language, the social basis of multilingualism can be exemplified to communicate and identify themselves through language. Language allows people to communicate with each other, share experiences, learn from each other and improve intellectuals.

In spoken language, it is commonly known that the notion of intonation greatly helps hear or listening activity, capture the meaning or sentence he or she hears. People often claim that Linguistics is the science of language or the science that makes the language as an object of study; or more precisely is the scientific study of human language. The word linguistics (is synonymous with linguistics in English, linguistique in French, and linguistiek in Dutch) comes from the Latin word Lingua which means language. In Roman languages, Latinspeaking languages, there are words similar to the Latin lingua such as lingua in Italian, lengue in Spanish, langue (and langage) in French, as well as a language in English that is picked it up from French langage. In French, there are two terms, namely langue and langage with different meanings. Langue means a particular language, such as English, Indonesian, Sasak, Sumbawa, or Bima. While langage means language in general.

Development efforts that can be done to improve the development of regional languages are by promoting local languages through various types of activities, one of them through work. Gold mining which is one of the

Alkapitani, M., Syahdan, -., \& Priyono, -. (2017). The enrichment of new vocabularies in Sasak language because of gold mining spreading in Sekotong west Lombok. International Journal Of Social Sciences And Humanities (IJSSH), 1(3), 182-193. doi:10.29332/ijssh.v1n3.129 
main commodities of Sekotong community requires a common vocabulary in the naming of an object with the intention that the communication existing across West Nusa Tenggara region in general with the same activities can be effectively established. These vocabularies are collected in a study and recorded in a book for later dissemination so that people who use the vocabulary really understand in the communication process.

There is no research examining the development of vocabulary, in particular, the addition of new words in the field of gold mining; therefore, the authors feel interested in examining the new vocabulary enrichment in Sasak language as a result of the proliferation of gold mines in Sekotong West Lombok.

\section{Theoretical Framework}

In this study, the researcher will describe some concepts becoming a reference and grounded theory of this research that is; the essence of the language itself and anything related to micro language. This study more examines micro part of language namely; the morphological part that focuses on the source or root of the word itself in terms of form and meaning. The essence of language can be seen in the explanation below.

Muhammad (2011) explains that language has 13 traits such as (1) it is a system, (2) it is a symbol, (3) the language is sound, (4) the language is arbitrary, (5) the language has meaning (7) the language is unique, (8) the language is universal, (9) the language is productive, (10) the language is varied, (11) the language is dynamic, (12) it serves as a tool of social interaction, and (13) it is the identity of the speaker.

For more details, researchers will describe the nature of language according to some experts, all of these things can be seen in the section below.

\section{1) Language is a system}

Chaer and Leonie (2010: 15) state that language is a system meaning that language is shaped by fixed and patterned components. According to some experts, it is clear that language is a system that has elements that cannot be separated that forms a unity that is closely related to each element. The language also has a scope of the system divided into two namely micro and macro. Micropart language system deals with the language itself that cannot be separated from study language itself while the macro part of a system sees the elements of language but requires a field of study other than the language itself.

\section{2) Language is A Symbol}

Language is also a symbol of conventional sound in an interrelated language speech between one symbol and other symbols and each symbol has meaning. All of this, according to the perspective of Chaer and Leonie (2010: 16-18) it is stated that language is a symbol of conventional folding sound. It means that every speaker of a language will obey the relationship between the symbol with which it symbolizes.

3) Language is A Sound

The language is a dynamic folding noise that can occur any time when it occurs from a vocabulary or lexicon changes in some languages. In this context, in accordance with the opinion of Chaer and Leonie (2010: 16-18) stating that the language symbol of sounds is dynamic. It means that the language cannot be separated from the various possible changes that can occur at any time. The change can occur at any level, either at the level of phonology, morphology, syntax, semantics, or lexicon. What seems clear is usually at the level of the lexicon. New vocabulary may appear anytime, but there is also an old vocabulary that is drowned, it is not used anymore.

4) Language is Arbitrary

Language is an arbitrary system of arbitrary sounds used by members of a society to be equal, intuitive and self-identifying (Linguistic Dictionary, 2001: 21). Language is an arbitrary symbol system used by members of social groups to work together, communicate, and identify (Kridalaksana, 1982: 2).

In this study, it will also describe the concept becoming the focus of discussion on this research namely; word etymology, the meaning of vocabulary. The explanations can be seen in the following section.

a) Word Etymology

The scope of the morphology belonging to the microlinguistic study that studies language in terms of the word in which the word is one of several forms of morphemes and morphemes is the scope of morphology. In this case, the researcher will describe the word meaning etymologically from based on 
experts such as Kridalaksana (1993: 98) stating that the word is the smallest unit that can be declared as a free form; independent units of language, occurring from a single morpheme (eg. stone, house, come, etc.), or a combination of morphemes (eg, warriors, following, pancasila 'five pillars of Indonesia', omnipotence, etc.).

The word is the smallest free grammatical unit. The word 'free' here is used in a grammatical sense, or in other words, it can be isolated (Ramlan, 1991: 7). While the opinion of Nurlina, et. al., (2004: 8) mentions the word, which is a unit of language that can stand alone, occurs from a single morpheme or a compound or bound morpheme. The different thing that Chaer proposes (1994: 162) is that the word is the unit of language that has one sense; or a word is a row of letters flanked by two spaces and has one word meaning that it can also be called free morpheme.

According to Kridalaksana (1991: 49), words class is divided into (1) Verbs, (2) adjective (3) Noun, (4) Pronoun (5) Numeral (6) Adverb (7) Interrogative 8) Demonstrativa (9) Articulate, (10) Preposition, (11) Conjunction, (12) phatic category 13) Interjection.

Based on the opinion of the experts above, all these things are closely related to morphological studies that are more pursed on the classification of words to be studied in this study, this is all, a reference for researchers. The researcher also emphasized that this research will focus on studying vocabulary or lexicon problem as well as classification of the language of Sekotong which is the Sasak language input that exists in gold mining activity in Sekotong.

\section{b) Definition of Vocabulary}

Language has concrete forms one of them is the word where the word is part of morpheme that has a lexical or grammatical meaning. The word is the smallest element of language that has meaning. For more details, the opinion of the expert namely; Chaer (2007: 6) puts forward some notion of vocabulary.

(1) All words contained in a language. In the case of Indonesian vocabulary, what is called as Indonesian vocabulary is all the words that exist in the Indonesian language as listed in Indonesian dictionaries. How many words contained in the Indonesian language cannot be specified precisely because they are part of a language system that is very susceptible to sociocultural changes and developments, so that the number may increase or decrease any time

(2) Words controlled by a person or group of people from the same environment. In this case, we can see the language of words controlled by the A, not as much as that controlled by the B, or the $\mathrm{C}$.

(3) Words or terms used in one area of activity or science.

In the study of the phenomenon of language use that is related to the micro part of language looking from the aspect of vocabulary or the turn of the word said is not close to the sphere of the language itself; by using the theory of language itself, while the theory used in this research is the theory of micro-part language namely Morphology by looking in terms of elements of language both form and meaning. For more details in this section, the researcher will describe some of the morphologically related features according to some experts in the section below.

Verhaar (2004: 97) explains that morphology is a linguistic branch that identifies the basic units of language as grammatical units. The basic definition of Verhaar is a unit of morpheme or word. Later on, he gives an example of a word 'berhak' (have the right) consisting of six phonemes and two morpheme that is ber- (prefix) and hak (right). Uhlenbeck (1982: 4) mentions morphology is the study of the systematic correlation of forms and meanings that exist in the words of a language. In morphology, it is also learned how the lexicon can be expanded systematically. Briefly, Ramlan (1980: 2) explains that morphology is a part of linguistics that studies the structure of words and the effect of word changes on class and meaning. Matthews (1974: 1) defines morphology as the study of word form. Bloomfield (1961: 207) defines that morphology is the construction of words and parts of words. From the above definitions, there is no fundamental difference. All the scholars agree that morphology is a linguistic branch that speaks of the formation of words.

Morphology is part of the branch of linguistics that explains the ins and outs of words that have meaning, as for the scope of morphology itself, including morphemes, morph and allomorph. For more details, it can be seen from opinions proposed by experts below.

Alkapitani, M., Syahdan, -., \& Priyono, -. (2017). The enrichment of new vocabularies in Sasak language because of gold mining spreading in Sekotong west Lombok. International Journal Of Social Sciences And Humanities (IJSSH), 1(3), 182-193. doi:10.29332/ijssh.v1n3.129 


\section{Morpheme, morph dan allomorph}

Verhaar (2004: 105) defines a morpheme as a grammatically minimal unit. Morph is the concrete form of the morpheme, and the allomorph is the realization of the morpheme, for example, the morpheme \{ber-\} composed of morph \{ber-\} in the word berjalan (walking), morphs \{be- $\}$ in the word bekerja (work), morph $\{$ bel $\}$ in the word belajar (learning). Morph $\{$ ber $\},\{$ be -$\}$, and $\{$ bel- $\}$ are allomorphs of morpheme $\{$ ber- $\}$. Katamba (1993: 24-26) also defines morphemes and morphs.

\section{"The morpheme is the smallest difference in the shape of a word that correlates with the smallest difference in word or sentence meaning or grammatical structure. A morph is a physical form representing some morpheme in a language. If different morph represents the same morpheme, they are grouped together and they are called allomorphs of that morpheme".}

Furthermore, S.C. Dik and J.G. Kooij (1994: 158) describe the morphemes and allomorphs, by exemplifying such as the words books, pens, and glasses. The three words are plural, but they are distinguished by three distinct markers / s /, / z /, and /iz/. These three forms are claimed as the same morphemes because they show phonological similarity and not mutual contradict. It means that no single English word has more than one of these plural suffixes. In other words, the suffixes are the complementary divisions. If one of the three arises, the other two forms do not appear. The appearance of each suffix between the three suffixes can be predicted on the basis of the phonological properties of the last phoneme at the word base of the noun. For example, / iz / comes at the base suffix / s /, / z /.

In other cases, there is no grammatical feature: one-word form such as homonymy, which refers to two meanings, usually as a single signature becoming singular and plural. Words such as sheep (plural): sheep (singular). Hindu linguists usually refer to it as a zero element: in the word sheep meaning plural, suffix marker is marked with zero. Besides this aforementioned notion, it should also be distinguished about the terms of basic morpheme, base form, root morpheme, and base morpheme (stem). Chaer (2003: 158) distinguishes the four forms. The term base morpheme is usually used as a dichotomy with affix morphemes. Based on the aforementioned description, it is clear that the concept of morphology is the scope of the micropart language, where the language has a range of them; phonology, morphology, syntax, semantics, and pragmatics. In this section of the study, the researcher will make one of the scopes of the language as a foundation in this research in helping examine the words that become the input of new words in Sekotong society.

\section{Research Methods}

Data sources in this study are the informants or sekotong community, the people who become gold miners in particular and Sekotong community in general. As this study is about new language with a new meaning so that anyone who becomes informants will deliver the same thing, not like people which explores history, since these languages and words have emerged since the existence of gold mine in Sekotong.

The authors argue that data is a tool to answer the research questions. Muhammad (2011) argues that there are three methods to present data. First is the provision of data that is done by observing the phenomenon of language or observation. It is called observation because it is done by observing the activity of the language. Observation can be done by maximizing the five senses, such as seeing, listening, feeling, sensing, thinking, etc. In the study of language, this method is usually called an observation method that can be done by maximizing five senses. The data resulted using this method are transcripts, field notes, narrations, descriptions.

Second is the interview method in language research. The data generated through this method by applying certain techniques is the transcription of the interview.

The third is a recording method that is by recording the activities done by people speaking by using video recorder, audio recorders and humans themselves. This method is faster to get data and facilitate researchers in the next data process, such as selecting and sorting data. 
Data Analysis

Data analysis method used by the researcher in this study is a qualitative descriptive method. The method of qualitative descriptive is as a procedure of problem-solving investigated, by describing the condition of the current research object on the basis of apparent facts. The facts as variables are more based on values rather than numbers. Qualitative research methods focus on the discovery of facts (fack ending) as the actual situation.

Mahsun (2005) argues that qualitative research processes are cyclical, starting from the discovery of problems, then formulating hypotheses, composing measurement tools (data provisioning instruments), carrying out the provision of data itself, data analysis, to data presentation analysis in the form of research reports. Furthermore, Mahsun also said that qualitative descriptive analysis is to focus on the performances of meaning, description, clarity, and placement of data in their respective contexts and often to describe words rather than numbers.

\section{Results and Analysis}

\section{Analysis of Data of New Vocabularies in Sekotong Community}

Based on data obtained researcher classify the findings before analysis stage where at this researcher describe the first data including data consisting of a few nouns which are identified as new vocabulary in Sekotong society, all of these findings can be seen on the table below.

\subsection{Analysis of Data of Noun}

In this section, researchers analyze part of the words of objects belonging to additional vocabulary in Sekotong community in the gold mining process that is not popular or familiar to the Sekotong community in doing interaction both with people from Sekotong community and with people from other community. This can be seen in the table below

Tabel 1

New Vocabularies in form of Noun in Sekotong community

\begin{tabular}{clcc}
\hline No & & Bahasa Indonesia & Word Class \\
\hline 1 & Lubang & & Noun \\
2 & Tong & Noun \\
3 & Ngetong & Noun \\
4 & Segabang & Noun \\
\hline
\end{tabular}

Based on the findings of the data in table 1 above, in this section researcher give the description of the data into the analysis stage as part of a noun by giving interpretation one by one from the data. The description can be seen in the section below.

1) Lubang (hole)

Based on table 1 above, the word hole is an addition to the vocabulary of Sekotong community in form of the noun. However, the word hole is previously understood by Sekotong community as an ordinary excavation that has synonym loang. Therefore, the word lubang is understood by Sekotong community with meaning that is people dig the mountain like a well about 10 meters in a group to avoid the wall falling down quickly and the miners can mine the gold safely.

2) Tong (barrel)

Another data which is in the form of the noun is the word tong. This word was previously not familiar to some people in this site and its meaning was only understood by some people. The word tong has similar meaning with the word blek in Sasak language meaning that a medium to retain or save paint and oil and so on. However, the word tong (barrel) in this section has the meaning of

Alkapitani, M., Syahdan, -., \& Priyono, -. (2017). The enrichment of new vocabularies in Sasak language because of gold mining spreading in Sekotong west Lombok. International Journal Of Social Sciences And Humanities

(IJSSH), 1(3), 182-193. doi:10.29332/ijssh.v1n3.129 
place/container used to process residue of mud to extract and release the gold. With this gold mining activity, Sekotog community has a lot of previously unknown language input.

3) Ngetong

The word ngetong is a part of the bound morpheme in from a noun that has the meaning of the residual of mud or stone containing gold which is reprocessed because not all gold cannot be extracted by using mercury.

4) Lumpur

Based on the data in the above table, the word mud also includes part of the common noun whose meaning is known by the general public that is mixing process between the soil with water. However, in this context, the word mud is meant as the residue of the gold stone that has been in the logs and cannot be extracted again so the mining process is done by way of pengetongan (see section 1.1.1 number 3).

\subsection{Analysis of Data of Verb}

In this section, researcher analyses the finding namely words including in the process of gold mining in Sekotong. The finding can be seen in this section as follows.

Tabel 2

New Vocabularies in Form of Vocabulary in Sekotong Community

\begin{tabular}{clc}
\hline No & Sasak Language & Word Class \\
\hline 1 & Begelondong & Verb \\
2 & Ngeloyong & Verb \\
3 & Belubang & Verb \\
4 & Ngecor & Verb \\
\hline
\end{tabular}

a) Begelondong

The word begelondong is a verb and in terms of the form, it belongs to bound morpheme where the word begelondong has the base word of the gelondong with prefix \{be-\} and its allomorph is begelondong. The word gelondong means a tool used to melt the stone. While begelondong means a process of taking gold from the golden stone. People usually take the gold through several processes in order to see the original gold taken from the golden stone.

b) Ngeloyong

In terms of the word, ngeloyong is categorised as a verb that indicates a process of activities in gold mines. However, people understand that the word ngeloyong means seeking golden stone around a gold location by looking for gold stone in the open or not-open in the hole.

c) Belubang

The word Belubang is categorized into a bonded verb. It indicates a noun meaning a location of gold mining like a well and this word has prefix \{be-\}. However, the word belubang means a process or activity of making a hole considered as a location that has many stones containing gold. The comparison is that the word belubang is equivalent to the word piak loang in Sasak language, while the word lubang is equivalent to the word loang. It can mostly be understood by Sekotong community and other communities.

\section{Conclusion}

Based on the above results and discussions, this study shows that there are some new vocabularies becoming the enrichment of Sasak language caused by the widespread of gold mining in Sekotong. This can be proved by some findings of data found by researchers at the research sites namely Sekotong area as the object of research. The empirical evidence shows that the existence of some new vocabulary that appears due to the activities of gold mining process namely; a new vocabulary consisting of several words classified the words found such as nouns, verbs, adjective, etc. Some of these classifications of these words that can be considered 
in the previous section were described in this study. After classifying the data, the data gathered were analyzed based on the theory used as a fundamental reference because this research is obviously using the theory of micro-linguistic that is by looking at the phenomenon of language use in terms of source or root of the words and this is related to the study of morphology. On this context, the researcher gives an explanation and concludes about the new words that become the enrichment of Sasak language in general and more specifically to Sekotong community. Therefore, it is clear that all of the findings is true with some empirical evidence found by researchers during the study took place.

Conflict of interest statement and funding sources

The authors declared that they have no competing interest. The study was financed by personal funding.

Statement of authorship

The authors have a responsibility for the conception and design of the study. The authors have approved the final article.

\section{Acknowledgments}

The researcher $\mathrm{s}$ to express his great gratitude to all people who have helped a lot during this study. To the author's parent who gives high motivation, prayer, and other non-material support. To all the lecturers in the master program of Indonesian language education who have been patiently sharing knowledge as long as the writers study in this program.

Alkapitani, M., Syahdan, -., \& Priyono, -. (2017). The enrichment of new vocabularies in Sasak language because of gold mining spreading in Sekotong west Lombok. International Journal Of Social Sciences And Humanities (IJSSH), 1(3), 182-193. doi:10.29332/ijssh.v1n3.129 


\section{References}

1. Alwi, H. (2007). Kamus besar bahasa Indonesia.

View in (Google Scholar)

2. Toha, M. A. dkk. 2007. Metode Penelitian. Jakarta: Univeristas Terbuka.

View in (Google Scholar)

3. Aridawati, I. A., Aridawati, I. A., Thoir, N., Thoir, N., Purwa, I. M., \& Purwa, I. M. (1995). Struktur Bahasa Sasak Umum (1995).

View in (Google Scholar)

4. Yulida Ashriany, R. (2009). Sistem Verba Bahasa Sasak Dialek Bayan Dari Dasar Verba Dan Nomina (Doctoral dissertation, Universitas Sebelas Maret Surakarta).

View in (Google Scholar)

5. Mardika, I. N. (2008). Pengembangan Multimedia dalam Pembelajaran Kosakata Bahasa Inggris di SD. Tersedia di http://mardikanyom. tripod. com/Multimedia. pdf.(Diakses pada Selasa, 27 September 2016). View in (Google Scholar)

6. Bloomfield, L. (1965). Language New York. Taylor \& Francis.

View in (Google Scholar)

7. Brown, P., Levinson, S. C., \& Levinson, S. C. (1987). Politeness: Some universals in language usage (Vol. 4). Cambridge university press.

View in (Google Scholar)

8. Bungin, B. (2001). Makna Realitas Sosial Iklan Televisi dalam Masyarakat Kapitalistik. Masyarakat, Kebudayaan dan Politik, 2, 51-64.

View in (Google Scholar)

9. Chaer, A. (2007). Leksikologi \& Leksikografi Indonesia. Rineka Cipta.

View in (Google Scholar)

10. Chaer, A. (2008). Morfologi bahasa Indonesia: pendekatan proses. Rineka Cipta.

View in (Google Scholar)

11. Chaer, A. (2012). Linguistik Umum (edisi baru). Jakarta: Rineka Cipta.

View in (Google Scholar)

12. Chaer, A., \& Agustina, L. (2004). Sosiolinguistik: perkenalan awal. Penerbit PT Rineka Cipta.

View in (Google Scholar)

13. Chaer, A., \& Agustina, L. (2004). Sosiolinguistik: perkenalan awal. Penerbit PT Rineka Cipta. View in (Google Scholar)

14. Ahmad, D. (1996). Penunjuk Peningkatan Mutu pendidikan di sekolah Dasar. Jakarta: Depdikbud. View in (Google Scholar)

15. Dik, S. C., Kooij, J. G., Kamil, T. W., \& Stokhof, W. A. L. (1994). Ilmu bahasa umum. RUL. View in (Google Scholar) 
16. de Saussure, F. Course in General Linguistics, edited by Charles Bally. Albert Sechehaye and Albert Reidlinger, translated by Wade Baskin (London, Fontana, 1974), 112.

View in (Google Scholar)

17. Martini, M., \& Nawawi, H. (1996). Penelitian Terapan.

View in (Google Scholar)

18. Kridalaksana, H. (1982). Kamus Linguistik Indonesia. Jakarta: Gramedia.

View in (Google Scholar)

19. Harimurti, K. (1993). Kamus Linguistik. Jakarta: Gramedia.

View in (Google Scholar)

20. Kridalaksana, H. (1989). Pembentukan kata dalam bahasa Indonesia. Gramedia pustaka utama. View in (Google Scholar)

21. Karap. (2014). "Berita dan Implikasinya Terhadap Pembelajaran Siswa Kelas VIII SMP Negeri 7 Pujut Tahun Pelajaran 2012/2013". TesisPascasarjana Universitas Mataram.

View in (PDF)

22. Katamba, F. (1993). Morphology, Houndsmill Basingstake.

View in (Google Scholar)

23. Keraf, G. (1991). Tata Bahasa Rujukan Bahasa Indonesia. Grasindo.

View in (Google Scholar)

24. Mahsun, M. S. (2005). Metode penelitian bahasa: tahapan strategi, metode dan tekniknya. PT RajaGrafindo Persada.

View in (Google Scholar)

25. Matthews, J. W., \& Blakeslee, A. E. (1974). Defects in epitaxial multilayers: I. Misfit dislocations. Journal of Crystal Growth, 27, 118-125.

View in (Google Scholar)

26. Bungin, P. D. H. B., \& Sos, S. (2005). Metodologi penelitian kuantitatif. Kencana.

View in (Google Scholar)

27. Muhadjir, N. (1989). Metode Penelitian. Raka Sarasin, Yogyakarta.

View in (Google Scholar)

28. Roekhan, \& Nurhadi. (1990). Dimensi-Dimensi dalam belajar bahasa kedua. Sinar Baru. View in (Google Scholar)

29. Ramlan, M. (1980). Ilmu bahasa Indonesia: morfologi. UP Karyono.

View in (Google Scholar)

30.Putra, A., Wijana, I. D. P., \& Ramlan, M. (2006). Sistem Morfologi Verba Bahasa Wakatobi Selatan Dialek Tomia= Morfological System of Verbs in Wakatobi languages Tomia Dialect. Humanika, 19(2006).

View in (Google Scholar)

31. Ramlan, M. (1983). Morfologi, suatu tinjauan deskriptif: ilmu bahasa Indonesia. Karyono. View in (Google Scholar)

Alkapitani, M., Syahdan, -., \& Priyono, -. (2017). The enrichment of new vocabularies in Sasak language because of gold mining spreading in Sekotong west Lombok. International Journal Of Social Sciences And Humanities (IJSSH), 1(3), 182-193. doi:10.29332/ijssh.v1n3.129 
32. Nasional, U. (2008). bahasa indonesia. Jakarta: Pusat Bahasa Departemen Pendidikan Nasional. View in (Google Scholar)

33. Syarifaturrahman, W. K., \& Hanafi, N. (2017). The Inflection of Sasak Language in Kuripan Village. International Journal of Social Sciences and Humanities (IJSSH), 1(3), 155-181.

View in (Google Scholar)

34. Wirawan, I. W. A. (2018). Maintaining Social Relationship of Balinese and Sasak Ethnic Community. International Journal of Social Sciences and Humanities (IJSSH), 2(1), 92-104.

View in (Google Scholar)

35. Yani, L., Artawa, K., \& Satyawati, N. M. S. (2018). Transitivity construction of verbal clause in Ciacia language. International Journal of Linguistics, Literature and Culture (IJLLC), 4(3), 15-23.

View in (Google Scholar) 


\section{Biography of Authors}

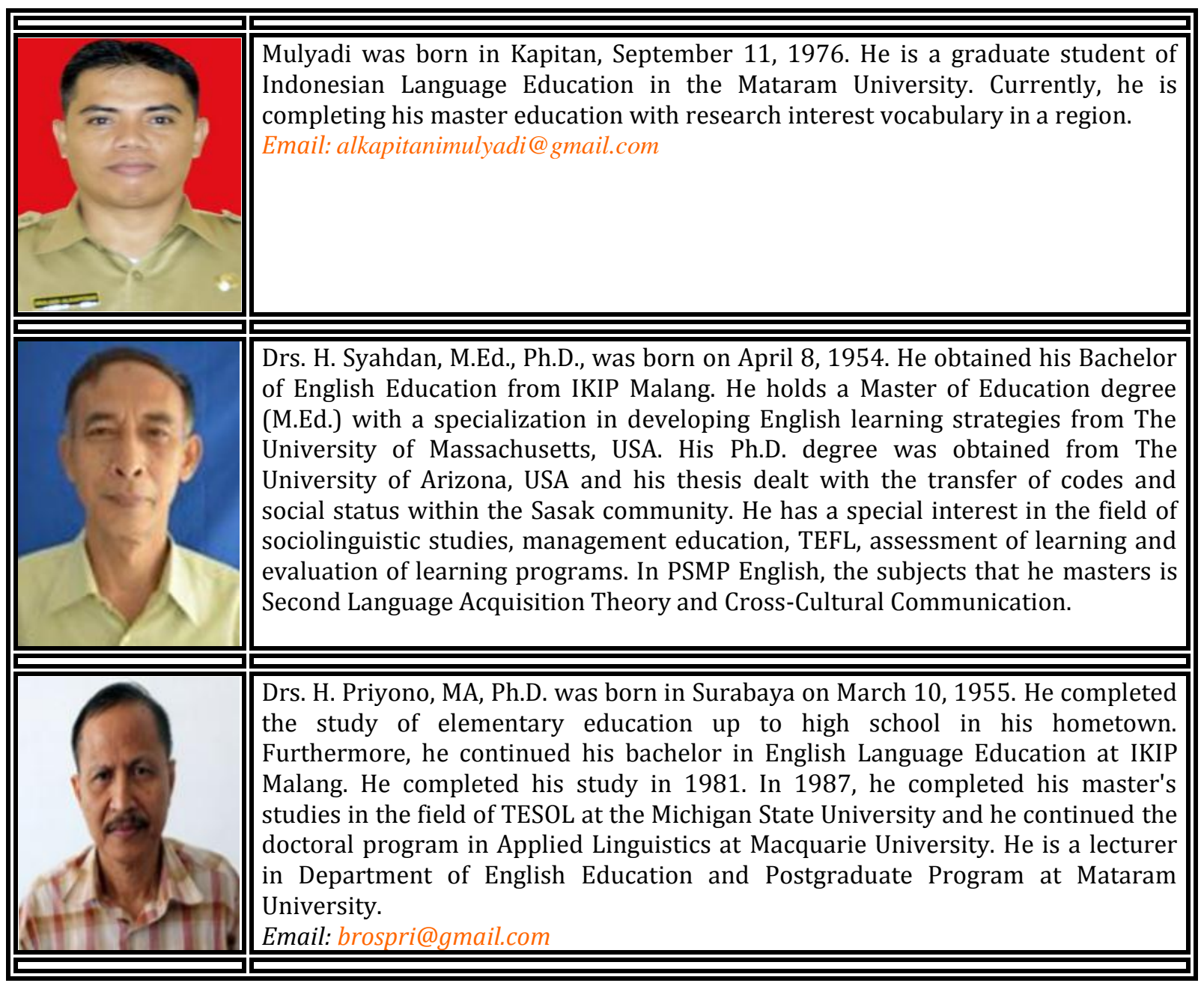

Alkapitani, M., Syahdan, -., \& Priyono, -. (2017). The enrichment of new vocabularies in Sasak language because of gold mining spreading in Sekotong west Lombok. International Journal Of Social Sciences And Humanities (IJSSH), 1(3), 182-193. doi:10.29332/ijssh.v1n3.129 